\title{
Isolation of putative embryo-specific genes using stress induction of carrot somatic embryos
}

\author{
Motoki Tanaka, Akira Kikuchi* and Hiroshi Kamada \\ Graduate School of Life and Environmental Sciences, University of Tsukuba, 1-1-1 Ten-noudai, Tsukuba, Ibaraki 305-8572, Japan
}

Little is known about the physiological responses of higher plant cells during the early stages of embryogenesis and the genes that are involved in these responses. Carrot is an appropriate plant for the study of somatic embryogenesis as a model of zygotic embryogenesis. The system of stress induction of carrot somatic embryogenesis is useful for isolating genes expressed during embryogenesis, as embryogenic competence and the expression of certain embryo-specific genes increases with increased stress. Fluorescent differential display (FDD) was performed to isolate stress-induced genes in carrot somatic embryos, and five genes were isolated as embryonic tissue-specific genes. One of these genes was expressed until the early torpedo-shaped stage of zygotic embryogenesis. This result suggested that in the stress-induction system of carrot somatic embryos, embryo-specific genes expressed in the early stages of embryogenesis were induced during somatic embryo induction by stress treatment, concomitant with acquisition of embryonic competence. Unique genes expressed during early embryogenesis can be isolated from carrot by combining the appropriate experimental system and FDD. This strategy could be applied to many plant species for which genome information is not yet available.

Key Words: embryogenesis, carrot somatic embryogenesis, stress induction, Fluorescent Differential Display.

\section{Introduction}

The data generated by plant genome projects, including those of Arabidopsis (Arabidopsis Genome Initiative 2000) and rice (International Rice Genome Sequencing Project 2005), are now in considerable use. The identification and isolation of target genes from these plants can be performed efficiently using these databases, and this information can also facilitate the isolation of homologous genes from plants for which little genome information is available. However, it can still be difficult to isolate and identify some unique genes from plants other than these model plants, such as some crop species and experimental plant species that are studied due to their unique characteristics. Embryogenesis in higher plants is one phenomenon that is most often studied in model plants for which little genome information is available.

During early embryonic development in higher plants, morphological development starts from the fertilized egg, and in late embryonic development the seed reserves needed for post-germination and metabolic quiescence leading to desiccation tolerance accumulate with the completion of pattern formation, as immature embryos become capable of germination (Goldberg et al. 1994, McCarty et al. 1995). Embryogenesis is regulated by many factors, and the expression of these factors is strictly controlled during development.

Communicated by T. Terachi

Received August 7, 2008. Accepted December 25, 2008.

*Corresponding author (e-mail: kikuike@sakura.cc.tsukuba.ac.jp)
Several embryo-specific genes have been identified and characterized in studies of Arabidopsis mutants. The embryo-specific transcription factors ABSCISIC ACID INSENSITIVE 3 (ABI3), LEAFY COTYLEDON 1 (LEC1), LEAFY COTYLEDON 2 (LEC2), and FUSCA3 are involved in embryonic morphogenesis and the acquisition of seed desiccation tolerance (Giraudat et al. 1992, Parcy et al. 1997, Lotan et al. 1998, Nambara et al. 2000, Stone et al. 2001). These transcription factors regulate the expression of $L E A$ class genes, which are involved in seed maturation and desiccation tolerance (Vicient et al. 2000, Nambara et al. 2000, Santos et al. 2005). Some molecular mechanisms of embryogenesis were elucidated from these studies, but it is difficult to identify genes that are important in early embryogenesis because the mutation of these genes is often lethal. Furthermore, embryogenesis occurs in very small areas within the ovules, leading to difficulties in analyzing expression patterns in developing embryos.

Somatic embryogenesis provides one way to circumvent these problems. Carrots constitute a good system to investigate somatic embryogenesis, as useful embryo induction systems have been developed for this species (Zimmerman 1993). Carrot somatic embryos can be readily induced synchronously, in large quantities, by the transfer of embryogenic cells (EC) from auxin-containing medium to auxinfree medium (Steward et al. 1958, Reinert 1959, Sung et al. 1984, Kiyosue et al. 1993a, 1993b). Long-term culture causes the EC to lose embryogenic competence and form small cell clusters consisting of non-embryogenic cells (NC) 
(Satoh et al. 1986). Several embryo-specific genes have been isolated and characterized by comparison of gene or protein expression in EC, NC, and somatic embryos (Wilde et al. 1988, Kiyosue et al. 1991, 1993a, 1993b, Lin et al. 1996, Tachikawa et al. 1998). Most of these genes were identified as $L E A$-class genes, and are expressed in the late stages of zygotic embryogenesis. Carrot homologs of $A B I 3$ $(C-A B 13)$ and $L E C 1$ ( $C-L E C 1)$ are also expressed in EC (Shiota et al. 1998, Yazawa et al. 2004), as are LEA-class genes (Wilde et al. 1988, Kiyosue et al. 1993a, 1993b). This suggests that embryo-specific genes expressed in early or late development are expressed simultaneously in EC, even though these cells do not exhibit morphological differentiation as embryos. Thus, it appears that the expression of genes involved in early embryonic development begins during EC induction, and it is therefore difficult to isolate genes expressed in the early stages of embryogenesis by comparing expression profiles between EC and other tissues.

However, it has been reported that carrot somatic embryogenesis can be induced from apical tip segments by treatment with high concentrations of sucrose (Kamada et al. 1989,1993 ) or $\mathrm{NaCl}$ (Kiyosue et al. 1989), high temperature (Kamada et al. 1994), or trace heavy metal ions, such as $\mathrm{Cd}^{2+}$ (Kiyosue et al. 1990), in phytohormone-free media. Somatic embryos can be induced from cells of explants by using these kinds of stress treatments followed by transfer to stress-free conditions. Such embryos are formed directly from surface cells of the explants, without visible callus formation. In this induction system, longer stress treatments result in higher frequencies of somatic embryo formation, with stronger expression of embryo-specific genes occurring before morphological differentiation into embryos (Tachikawa et al. 1998, Kikuchi et al. 2006). As somatic cells of explants acquire embryogenic competence during stress treatment, and the degree of embryo formation is enhanced by increased treatment duration (Kikuchi et al. 2006), some embryo-specific genes expressed in early embryogenesis are also likely to be expressed during the stress treatment, with their expression levels increasing with the duration of the stress treatment. Therefore, the carrot system was used in an attempt to isolate genes related to the early stage of embryogenesis.

Recently, microarray analysis has been extensively used for comprehensive comparisons of gene expressions between different conditions (treatments). This is quite a powerful method for the study of gene expression, but large numbers of gene sequences are essential for the production of microarray slides, i.e. the tool is one of the outcomes of genome projects. Macroarray analysis does not need sequence information, but is inadequate for large-scale comparisons of gene expression, since it requires cloning steps. Macroarray analysis is usually employed after identifying some candidate genes. In contrast, fluorescent differential display (FDD) is one of the most appropriate methods for large-scale comparisons of gene expression in species with little available genome information. This method needs no specialized equipment except the a fluorescent gel scanner to detect fluorescent signals since it uses fluorescent labeling. In this study, the stress-induction system in carrot was used with FDD in an attempt to isolate novel earlyembryogenesis-related genes. A unique gene expressed during early embryogenesis was isolated from carrot. By combining the appropriate experimental system and FDD, this strategy could be applied to many plant species for which genome information is lacking.

\section{Materials and Methods}

\section{Plant material}

Daucus carota L. cv. US-Harumakigosun (Ueki Seed Co. Ltd., Yokohama, Japan) was used. The plant materials collected were true leaves from 4-week-old plants, immature seeds from different plants at 3, 15, 21, 27, 36, 45, and 54 days after flowering (DAF), and mature dry seeds. Embryogenic cells (EC) and somatic embryos were induced as described (Tachikawa et al. 1998), and non-embryogenic cells (NC) that had lost the ability to form somatic embryos were used as negative controls for the acquisition of embryogenic competence (Satoh et al. 1986). Murashige and Skoog (MS) media (Murashige and Skoog 1962) with or without $1 \mathrm{mg} / \mathrm{l}$ 2,4-dichlorophenoxyacetic acid (2,4-D) were used as the basal media for this experiment. EC and NC were subcultured at 2-week intervals, and harvested tissues and cells were immediately frozen in liquid nitrogen and stored at $-80^{\circ} \mathrm{C}$ until use.

\section{Stress and auxin treatment}

To induce somatic embryos, sucrose-stress and auxin treatments were performed as described (Kikuchi et al. 2006). For the sucrose-stress treatment, apical tip explants of 9-dayold-seedlings were cultured on phytohormone-free MS solid medium $(0.8 \%$ agar, $w / v)$ containing $0.7 \mathrm{M}$ sucrose for 4 or 14 days at $25^{\circ} \mathrm{C}$. For the auxin treatment, apical tip explants of 9-day-old-seedlings were cultured on MS solid medium $(0.8 \%$ agar, w/v) containing $1 \mathrm{mg} / 1$ 2,4-D for 3 days. As a negative control, explants were cultured on phytohormonefree MS solid medium ( $0.8 \%$ agar, w/v) containing 3\% (w/v) sucrose, without stress treatment or 2,4-D for 3 days, in which duration the explants should be recovered from the wound stress and have not developed true leaves. The tissues were harvested, frozen immediately in liquid nitrogen, and stored at $-80^{\circ} \mathrm{C}$ until use.

\section{Fluorescent differential display (FDD)}

Total RNA was isolated from stress-treated explants $(0.7$ $\mathrm{M}$ sucrose for 4 or 14 days) and negative controls using the phenol/SDS method (Ausubel et al. 1987). Aliquots of $20 \mu \mathrm{g}$ of total RNA were incubated with 10 units of DNase I (Roche Diagnostics, Mannheim, Germany) for $20 \mathrm{~min}$ at $37^{\circ} \mathrm{C}$, extracted with phenol/chloroform, and the RNA recovered by ethanol precipitation. FDD was performed using a Fluorescence Differential Display kit, Rhodamine version 
(TaKaRa Bio, Otsu, Japan), according to the manufacturer's protocol. First-strand cDNAs were synthesized from total RNA (200 ng) using nine different rhodamine-labeled primers and reverse transcriptase in a $20-\mu 1$ volume using an Enzyme Set-FDD (TaKaRa Bio). The synthesized cDNAs were amplified by PCR using combinations of nine downstream primers and 24 upstream primers for a total of 216 PCR operations. PCR was done with TAKARA LA Taq (Takara Bio). The PCR conditions were as follows: $94^{\circ} \mathrm{C}$ for $2 \mathrm{~min}, 40^{\circ} \mathrm{C}$ for $5 \mathrm{~min}$, and $72^{\circ} \mathrm{C}$ for $5 \mathrm{~min}$, followed by 34 cycles of $94^{\circ} \mathrm{C}$ for $30 \mathrm{~s}, 40^{\circ} \mathrm{C}$ for $2 \mathrm{~min}$, and $72^{\circ} \mathrm{C}$ for $1 \mathrm{~min}$, with an additional step at $72^{\circ} \mathrm{C}$ for $5 \mathrm{~min}$. The PCR products were electrophoresed on $6 \%$ polyacrylamide gels, and the signals of the amplified fragments were detected with a Molecular Imager FX (Bio-Rad, Hercules, CA). All fragments with signal intensities that were higher in the stresstreatment group than in the control were excised from the gels, and the fragments were eluted into distilled water using Freeze'N Squeeze DNA Gel Extraction Spin Columns (Bio$\mathrm{Rad})$. The samples were then re-amplified by PCR with the same primer sets used in the first PCR under the following conditions: $94^{\circ} \mathrm{C}$ for $2 \mathrm{~min}$, followed by 15 cycles of $94^{\circ} \mathrm{C}$ for $30 \mathrm{~s}, 40^{\circ} \mathrm{C}$ for $2 \mathrm{~min}$, and $72^{\circ} \mathrm{C}$ for $1 \mathrm{~min}$. The PCR products were electrophoresed on $3 \%$ NuSieve $3: 1$ agarose gels (TaKaRa Bio) containing $1 \mathrm{U} / \mathrm{ml}$ H.A. Yellow (GeneScan Europe AG, Freiburg, Germany), a base-specific DNA ligand that binds preferentially to A and T (Müller et al. 1997). All DNA bands with signal intensities that showed the same tendency as in the first PCRs were excised from the gel and purified using Freeze'N Squeeze DNA Gel Extraction Spin Columns. The purified DNA fragments were amplified in a third round of PCR with appropriate sets of extended primers. The extended upstream primers were comprised of the upstream primer with an M13-reverse primer sequence (5'-GAGCGGATAACAATTTCACACAGG-3') at the 5' end, and the extended downstream primers were comprised of the downstream primers with an M13-20 primer sequence (5'-CGACGTTGTAAAACGACGGCCAGT-3') at the 5' end. Amplification was performed under the following conditions: $94^{\circ} \mathrm{C}$ for $2 \mathrm{~min}$, followed by 40 cycles of $94^{\circ} \mathrm{C}$ for $30 \mathrm{~s}, 40^{\circ} \mathrm{C}$ for $30 \mathrm{~s}$, and $72^{\circ} \mathrm{C}$ for $30 \mathrm{~s}$, and an additional incubation for $5 \mathrm{~min}$ at $72^{\circ} \mathrm{C}$ after the final cycle. The PCR products were electrophoresed on a $3 \%$ NuSieve $3: 1$ agarose gel containing $1 \mathrm{U} / \mathrm{ml}$ H.A. Red (GeneScan), a base- specific DNA ligand that binds preferentially to $\mathrm{G}$ and $\mathrm{C}$, and the bands were excised from the gel. These DNA fragments were purified with the Wizard SV Gel and PCR Clean-Up System (Promega, Madison, WI) and subcloned into the pGEM-T Easy Vector (Promega).

\section{Macroarray analysis}

Selected FDD clones were amplified from subcloned plasmids using T7 sequence (5'-TAATACGACTCACTAT AGGG- $\left.3^{\prime}\right)$ and SP6 sequence (5'-ATTTAGGTGACACTA TAG-3') primers under the following conditions: $94^{\circ} \mathrm{C}$ for $2 \mathrm{~min}$, followed by 40 cycles of $94^{\circ} \mathrm{C}$ for $45 \mathrm{~s}, 55^{\circ} \mathrm{C}$ for $45 \mathrm{~s}$, and $72^{\circ} \mathrm{C}$ for $1 \mathrm{~min}$. Around $1 \mu \mathrm{g}$ of PCR products and DNA fragments of an internal control gene, glyceraldehyde-3phosphate dehydrogenase $(G A P D H)$, were spotted onto Biodyne B nylon filters (Pall BioSupport, East Hills, NY) using a Milli Blot Kit (Millipore, Bedford, MA) and the vacuum transfer method according to the manufacturer's protocol. Poly $(\mathrm{A})^{+}$RNA was extracted and purified from stresstreated $(0.7 \mathrm{M}$ sucrose for 4 or 14 days) and negative-control explants using a Micro-FastTrack 2.0 kit (Invitrogen, Carlsbad, CA) according to the manufacturer's instructions. ${ }^{32} \mathrm{P}$-labeled cDNA probes were synthesized from $300 \mathrm{ng}$ of poly $(\mathrm{A})^{+}$RNA using ${ }^{32} \mathrm{P}-\mathrm{dCTP}$ and the SuperScript FirstStrand Synthesis System for RT-PCR (Invitrogen), and hybridized to the filters in a solution containing $0.5 \mathrm{M}$ $\mathrm{Na}_{2} \mathrm{HPO}_{4}, 1 \mathrm{mM}$ EDTA, 7\% SDS, and $1 \mathrm{~g} / 1$ poly-d(A) ${ }^{+}$for $20 \mathrm{~h}$ at $65^{\circ} \mathrm{C}$. The filters were washed twice with $0.2 \times \mathrm{SSC}$ containing $0.1 \% \mathrm{SDS}$ for $15 \mathrm{~min}$ at $65^{\circ} \mathrm{C}$ and then exposed to an imaging plate for $20 \mathrm{~h}$, and the signal intensity of each spot was quantified using a BAS5000 Bioimaging Analyzer (Fuji Photo Film, Tokyo, Japan). The signal intensity of each spot was normalized against that of GAPDH.

\section{Expression analysis by RT-PCR}

cDNA was synthesized from $1 \mu \mathrm{g}$ of total RNA using the SuperScript First-Strand Synthesis System for RT-PCR and isolated by the SDS-phenol method, and expression analysis of sucrose-stress and 2,4-D treatments was performed using RT-PCR. Each gene was amplified using specific primers (Table 2) under the following conditions: $94^{\circ} \mathrm{C}$ for $2 \mathrm{~min}$, followed by $15-40$ cycles of $94^{\circ} \mathrm{C}$ for $30 \mathrm{~s}, 55^{\circ} \mathrm{C}$ for $30 \mathrm{~s}$, and $72^{\circ} \mathrm{C}$ for $1 \mathrm{~min}$. Specific PCR products were distinguished by Southern hybridization using FDD clones. The PCR

Table 1. Sequence characteristics of cDNAs isolated by FDD

\begin{tabular}{|c|c|c|c|c|}
\hline Clone name & $\begin{array}{l}\text { Isolated cDNA } \\
\text { length (nt) }\end{array}$ & $\begin{array}{l}\text { Accession } \\
\text { number }\end{array}$ & $\begin{array}{l}\text { Putative protein encoded by homologous gene; } \\
\text { accession number }\end{array}$ & Score $(\mathrm{S})$ and E-value $(\mathrm{E})^{*}$ \\
\hline$A-6-2$ & 663 & X53851 & DcHsp17.7 [Daucus carota]; P27396 & $S=190, E=6 e-47$ \\
\hline$B-9-2$ & 1,069 & AB361241 & no homology & \\
\hline$C-2-3$ & 957 & AB361242 & seed maturation protein PM34 [Soybean]; AAF89645 & $\mathrm{S}=399, \mathrm{E}=7 \mathrm{e}-109$ \\
\hline$C-8-1$ & 1,009 & AB361243 & Alpha-TIP [Arabidopsis thaliana]; NP_177462 & $\mathrm{S}=297, \mathrm{E}=7 \mathrm{e}-79$ \\
\hline$E-14-2$ & 740 & AB361244 & $\begin{array}{l}\text { zinc finger (C3HC4-type RING finger) family protein } \\
\text { [Arabidopsis thaliana]; NP_199035 }\end{array}$ & $\mathrm{S}=95, \mathrm{E}=9 \mathrm{e}-24$ \\
\hline
\end{tabular}

\footnotetext{
* BLAST score (S) and expectation value (E) determined using BLASTX.
} 
products were electrophoresed in $2 \%$ agarose gels and transferred to Biodyne B nylon filters. The filters were hybridized with ${ }^{32} \mathrm{P}$-labeled FDD clones in a solution containing $0.5 \mathrm{M}$ $\mathrm{Na}_{2} \mathrm{HPO}_{4}, 1 \mathrm{mM}$ EDTA, 7\% SDS, and $150 \mu \mathrm{g} / \mathrm{ml}$ herring sperm DNA for $20 \mathrm{~h}$ at $65^{\circ} \mathrm{C}$. The filters were washed twice with $0.2 \times \mathrm{SSC}$ containing $0.1 \%$ SDS for $15 \mathrm{~min}$ at $65^{\circ} \mathrm{C}$, exposed to an imaging plate, and the signal intensity of each band was quantified using a BAS5000 Bioimaging Analyzer.

Amplifications for expression analysis in somatic embryos and immature seeds were performed under the following conditions: $94^{\circ} \mathrm{C}$ for $2 \mathrm{~min}$, followed by $28-42$ cycles of $94^{\circ} \mathrm{C}$ for $30 \mathrm{~s}, 55^{\circ} \mathrm{C}$ for $30 \mathrm{~s}$, and $72^{\circ} \mathrm{C}$ for $1 \mathrm{~min}$. The PCR products were electrophoresed in $2 \%$ agarose gels and quantified with a Molecular Imager FX after ethidium-bromide staining.

\section{5'-RACE analysis \\ 5'-Rapid Amplification of cDNA Ends (5'-RACE) was}

Table 2. Sequences of specific primer sets used in RT-PCR

\begin{tabular}{|c|c|c|}
\hline$A-1-1$ & A-1-1 Fwd & 5'-TGCGAGCAGTGTGAGCA-3' \\
\hline$(154 b p)$ & A-1-1 Rev & 5'-CGGAGGGCAGCTTCAA-3' \\
\hline$A-6-2$ & A-6-2 Fwd & 5'-GGTGACCGTGCCGAAA-3' \\
\hline (152 bp) & A-6-2 Rev & 5'-CACAGGACTCCAGAGACAACA-3' \\
\hline$B-6-4$ & B-6-4 Fwd & 5'-GACCGTGTTTGGGTTTGG-3' \\
\hline$(187 b p)$ & B-6-4 Rev & 5'-CCGGTAGAGAGATCTTAGCAGA-3' \\
\hline$B-9-2$ & B-9-2 Fwd & 5'-TTTCGCAGGCAGAACCA-3' \\
\hline (194bp) & B-9-2 Rev & 5'-TGGCTAGGGAGAGCACAA-3' \\
\hline$B-9-3$ & B-9-3 Fwd & 5'-GGCGGTGTTCCCTGGT-3' \\
\hline$(165 b p)$ & B-9-3 Rev & 5'-TGCCAGAGCTACCAGACC-3' \\
\hline$C-2-3$ & C-2-3 Fwd & 5'-GCTTGATGGGGAGATCTGG-3' \\
\hline$(154 \mathrm{bp})$ & C-2-3 Rev & 5'-CATTACAACACTTGCTT \\
\hline$C-8-1$ & C-8-1 Fwd & 5'-TTTTGGCTCCAGAAAGACT-3' \\
\hline$(150 \mathrm{bp})$ & C-8-1 Rev & 5'-CAACACAAACAAAAGGGTTC \\
\hline$D-9-4$ & D-9-4 Fwd & 5'-AACGATTTGCCGGGTGT-3' \\
\hline$(101 b p)$ & D-9-4 Rev & 5'-AAATGCCATCGTCAAACG-3' \\
\hline$D-20-1$ & D-20-1 Fwd & 5'-TCCCCAGGCTGATCCA-3' \\
\hline$(149 b p)$ & D-20-1 Rev & 5'-TCGGGATTTGTGCAGGA-3' \\
\hline$E-11-1$ & E-11-1 Fwd & 5'-GGAGCTTATTCGCAC-3' \\
\hline (156bp) & E-11-1 Rev & 5'-GGATGTTCTTGTG \\
\hline$E-14-2$ & E-14-2 Fwd & 5'-GGAACCAATCCCTGCTAGA-3' \\
\hline (167bp) & E-14-2 Rev & 5'-TCAAAAATACGAGAACACAGTT-3' \\
\hline$E-20-3$ & E-20-3 Fwd & 5'-CACCCTGCTGCTCATGC-3' \\
\hline$(161 b p)$ & E-20-3 Rev & 5'-AGCCCCGCCAGTGAAC-3' \\
\hline$F-17-1$ & F-17-1 Fwd & 5'-CGTGATTGCTAAGGCTGA-3' \\
\hline$(115 b p)$ & F-17-1 Rev & 5'-TCCTTGGCCCCATTTG-3' \\
\hline$F-18-3$ & F-18-3 Fwd & 5'-GGCGCCCATCTGCTAA-3' \\
\hline$(219 b p)$ & F-18-3 Rev & 5'-TTCGCAAGCAAAGAACAA-3' \\
\hline$F-19-1$ & F-19-1 Fwd & 5'-CAATGCGATGAAAGATGC-3' \\
\hline (163 bp) & F-19-1 Rev & 5'-CAGCAGAGTTTCCCCTGA-3' \\
\hline$H-9-1$ & H-9-1 Fwd & 5'-GGCTCCCGCCAAGGTA-3' \\
\hline$(165 b p)$ & H-9-1 Rev & 5'-TGCCTGGCTTGGCATC-3' \\
\hline$H-11-1$ & H-11-1 Fwd & 5'-TTGCAGGGACTGCAGGA-3' \\
\hline$(215 b p)$ & H-11-1 Rev & 5'-CTCCGGTTGGTCTTCTGA-3' \\
\hline$I-2-2$ & I-2-2 Fwd & 5'-GAGAAGGAATCAGAC-3' \\
\hline (182 bp) & I-2-2 Rev & 5'-GGAGCTTATTCGCAC-3' \\
\hline$G A P D H$ & GAPDH Fwd & 5'-GATGTCTCTGTCGTTGAT-3' \\
\hline (231 bp) & GAPDH Rev & 5'-ATCGTACCACGAAACAAG-3' \\
\hline
\end{tabular}

performed using $200 \mathrm{ng}$ of total RNA from explants stressed with $0.7 \mathrm{M}$ sucrose for 14 days and specific 5'-RACE PCR primers (Table 3) with a SMART RACE cDNA Amplification Kit (BD Biosciences Clontech, Palo Alto, CA) according to the manufacturer's protocol.

\section{Sequence analysis}

Cloned FDD fragments from individual plasmids were sequenced by the dye-terminator cycle sequencing method using a BigDye Terminator Cycle Sequencing kit (Applied Biosystems, Foster City, CA) according to the manufacturer's protocol. Sequence homology analysis was performed using BLAST and BLASTX (National Center for Biotechnology Information; Basic Local Alignment Search Tool 2.0).

\section{Results}

Identification of carrot stress-induced genes by FDD and macroarray analysis

Approximately 20,000 cDNA fragments were amplified using FDD, and over 200 showed higher intensity upon sucrose-stress treatment (4 or 14 days) as compared to controls (Fig. 1). The reproducibility of the band profiles was confirmed by re-amplification; some fragments failed to amplify. Finally, 142 cDNA fragments were isolated as clones that are inducible by sucrose stress.

After the cloning of these 142 fragments, macroarray analysis was performed to obtain an estimate of their expression levels during sucrose-stress treatment (Fig. 2). In three replicates of the analysis, 27 clones showed more than twice the signal intensity in explants exposed to a 14-day stress treatment than in controls. Sequencing analysis of partial fragments of each clone revealed that nine had already been isolated from carrot somatic embryos and characterized as ECP31 and DC59 (Hatzopoulos et al. 1990, Kiyosue et al. 1992). These nine clones were therefore eliminated from further analysis. As macroarray analysis detects signals through hybridization, there is some risk of detection of homologous genes. To examine this possibility, the expression of the 18 remaining stress-inducible clones was analyzed by RT-PCR (Fig. 3). Each putative cDNA was amplified using specific primer sets designed based on the sequence of the corresponding FDD clone. No expression was detected for three genes (F-17-1,H-9-1, and I-2-2). Three other genes (E-11-1, F-18-3, and H-11-1) showed increased expression after 3 days of stress treatment, but their expression levels had decreased by 14 days of treatment. The remaining 12

Table 3. Sequences of specific primers used in 5'-RACE PCR

\begin{tabular}{ll}
\hline \hline$A-6-2$ & 5'-CCGGTCCTAGCCGGAGATGTCAATA-3' \\
$B-9-2$ & 5'-GTAACACTCCACCGAATCCGCCTTG-3' \\
$C-2-3$ & 5'-GCAGCATATCCCAGATCTCCCCATC-3' \\
$C-8-1$ & 5'-CACACAGCTCCTTGAAACAGAACACC-3' \\
$E-14-2$ & 5'-TGGCAAAAATCCGTCACAGAAAG-3'
\end{tabular}


A

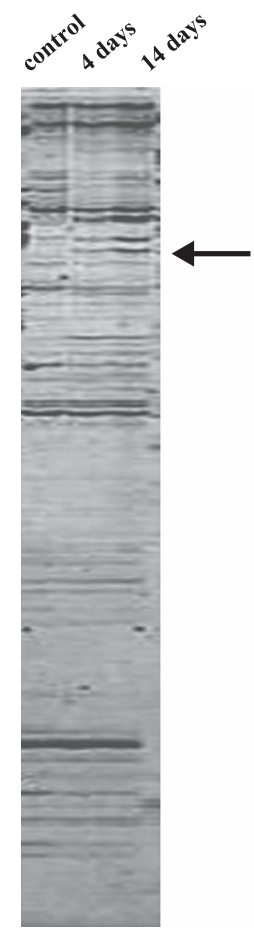

B

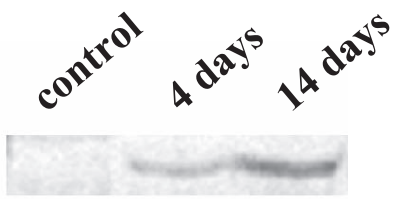

the 12 genes were expected to increase upon 2,4-D treatment. To verify the genetic response to 2,4-D, expression analyses were performed using RT-PCR (Fig. 4). The expression of the genes $A-1-1, B-6-4$, and $F-19-1$ did not change, but the remaining nine genes responded to the treatment.

Next, to analyze whether these nine genes were expressed specifically in embryonic tissues, their expression was examined in embryonic and non-embryonic tissues (Fig. 5). Four genes (B-9-3, D-9-4, D-20-1, and E-20-3) were expressed in non-embryonic tissues, including non-embryogenic cells (NC) and leaves. In contrast, five genes ( $A-6-2, B-9-2$, $C-2-3, C-8-1$, and $E-14-2)$ were expressed in embryonic cells (EC) or somatic embryos (SE), but not in NC or leaves.

Expression profiles of candidate genes during zygotic embryogenesis

To examine the expression profiles of the five selected genes during zygotic embryogenesis, their expression was analyzed in developing seeds from 3 days after flowering (DAF) to maturity (Fig. 6). The expression of $A-6-2$ began at $9 \mathrm{DAF}$ and was maintained to seed maturity. The expression of $B-9-2, C-2-3$, and $C-8-1$ began at $21 \mathrm{DAF}$ and continued to maturity. In contrast, the expression of $E-14-2$ started at 3

Fig. 1. Screening of sucrose stress-induced genes by FDD. (A) Polyacrylamide gel electrophoresis of PCR products. FDD products were generated from total RNA of explants cultured without treatment for 3 days (control) or treated with $0.7 \mathrm{M}$ sucrose for 4 or 14 days. Arrows indicate bands of interest. The bands were excised from the gel and subjected to further analysis. (B) Example of an enlarged image of a band of interest showing increased band intensity with increased duration of stress treatment. The band was identified as $E C P 31$ by further analyses.

genes showed increased expression throughout the length of the sucrose-stress treatment.

Evaluation of the embryo-specific expression of the stressinducible genes

As somatic embryos are generally induced by auxin treatment (Kamada and Harada 1979), the expression levels of

DAF, with the highest levels at 21 DAF, but decreased rapidly after $27 \mathrm{DAF}$. In addition, the expression level of $E$-142 in developing seeds was lower than in stress-treated apical tip explants.

\section{Identification of candidate clones}

All FDD-isolated clones represent only the $3^{\prime}$ ends of the cDNA. To obtain longer open reading frames, $5^{\prime}$-RACE PCR was performed. Characteristics of obtained cDNA sequences were summarized in Table 1 . The cDNA sequences were compared with the NCBI nucleotide and peptide sequence databases using BLAST and BLASTX. B-9-2 showed no homology to reported gene or protein sequences, but the four other cDNAs showed some homology to registered plant genes or proteins (Table 1). A-6-2 encodes heat

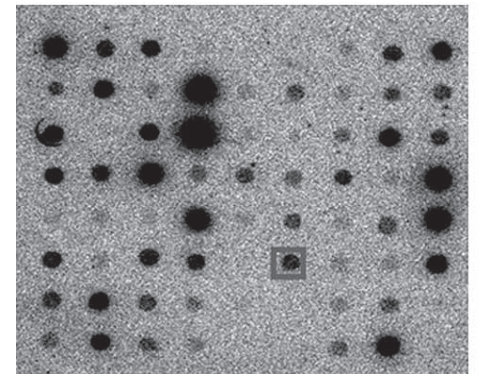

control

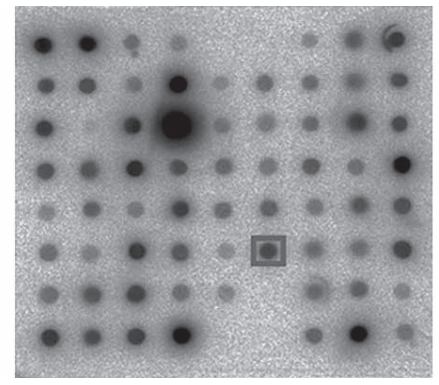

4 days

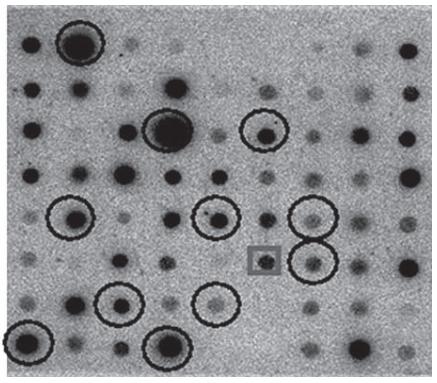

14 days

Fig. 2. Macroarray analysis of cloned FDD products. Panels show macroarray images after hybridization with radiolabeled cDNA. cDNAs were synthesized from poly(A) ${ }^{+}$RNA isolated from explants cultured without treatment for 3 days (control) or treated with $0.7 \mathrm{M}$ sucrose for 4 or 14 days. The spot in the square is the internal control gene glyceraldehyde-3-phosphate dehydrogenase (GAPDH). The circles indicate clones for which expression was enhanced by more than twofold upon stress treatment after normalization with the GAPDH signal. 


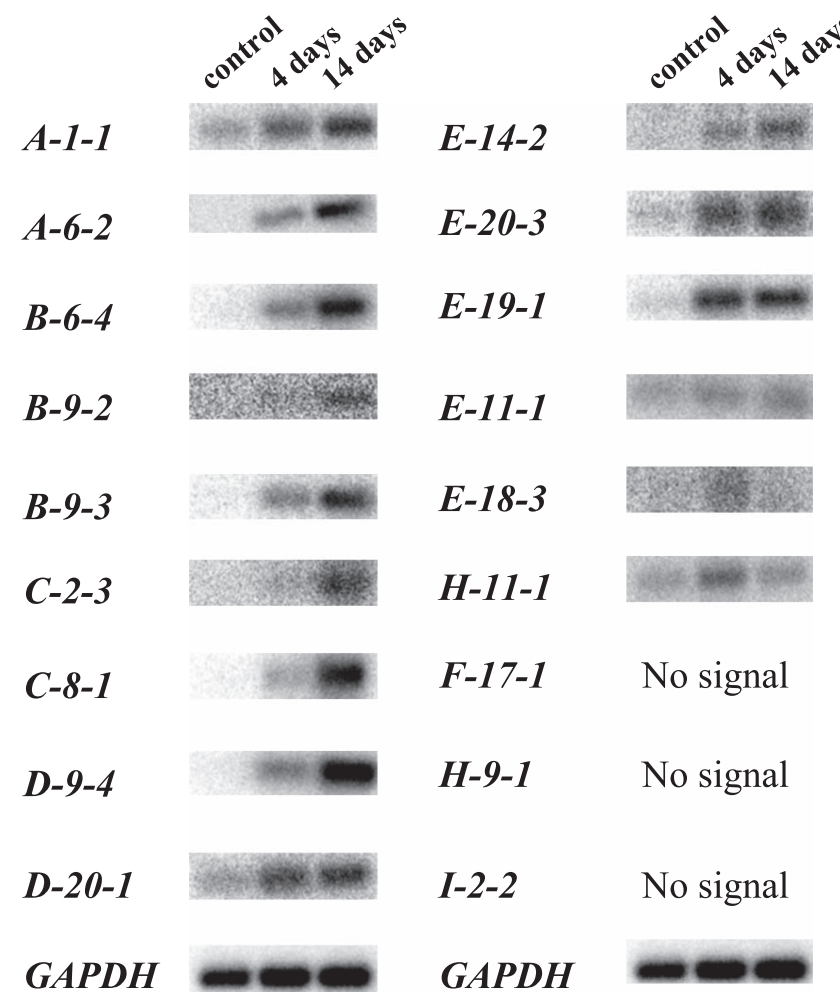

Fig. 3. Expression analysis of candidate FDD clones during sucrose stress treatment. cDNAs were synthesized from total RNA isolated from explants cultured without treatment for 3 days (control) or treated with $0.7 \mathrm{M}$ sucrose for 4 or 14 days. The genes were amplified using specific primer sets and hybridized with radiolabeled FDD clones. The expression of $E-11-1, F-18-3$, and $H-11-1$ was not enhanced by stress treatment. $G A P D H$ was used as an internal standard. No expression was detected from $F-17-1, H-9-1$, or $I-2-2$.

shock protein 17.7 (Hsp17.7) isolated from Daucus carota somatic embryos (Darwish et al. 1991). The predicted amino acid sequence of $C-2-3$ is homologous to the sequence of the soybean seed maturation protein PM34 (accession number AAF89645), which is similar to the sequences of glucose and ribitol dehydrogenase. The predicted peptide sequence of $C-8-1$ is homologous to the sequence of tonoplast intrinsic protein (TIP), a member of one of the major intrinsic protein (MIP) subfamilies. MIPs facilitate the bidirectional transport of water and certain small solutes across the membrane (Agre et al. 2002, Thomas et al. 2002). The predicted peptide sequence of $E-14-2$ is homologous to a ubiquitin ligase containing a RING-finger (Really Interesting New Gene) domain, which is a specialized type of $\mathrm{Zn}$ finger of 40 to 60 residues that binds two atoms of zinc (Freemont 1993, Joazeiro et al. 2000).

\section{Discussion}

In most cases, the first step in the initiation of somatic embryogenesis is the induction of embryogenic cells from somatic cells of explants. Many types of embryo-specific

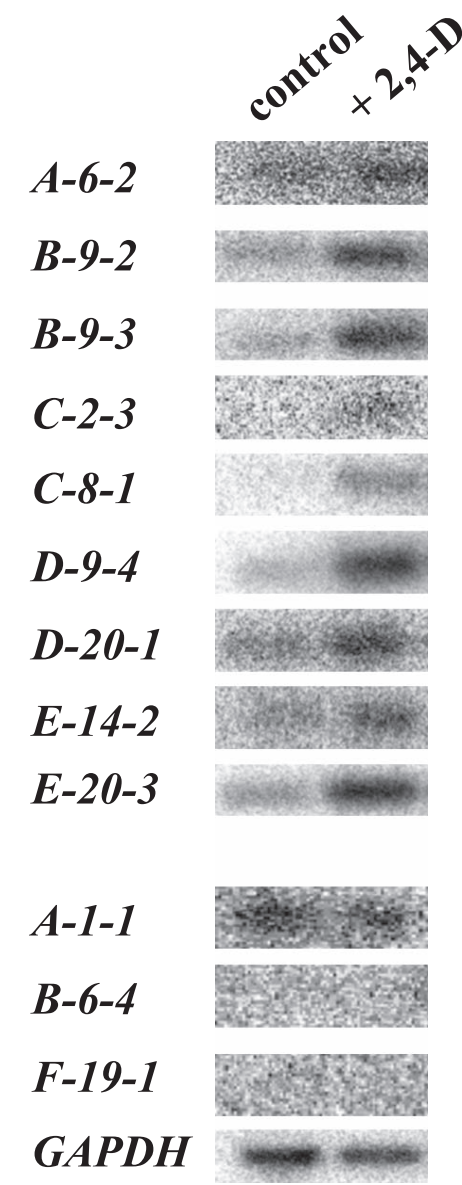

Fig. 4. Expression analysis of candidate FDD clones during auxin treatment by RT-PCR. cDNAs were synthesized from total RNA isolated from explants cultured without 2,4-D (control) or with 2,4-D (1 $\mathrm{mg} / \mathrm{ml}$ ) for 3 days (+2,4-D). The genes were amplified using specific primer sets and hybridized with radiolabeled FDD clones. GAPDH was used as an internal standard. The expression levels of $A-1-1, B-6-$ 4, and F-19-1 did not change with 2,4-D treatment.

genes, including $L E A$-class genes, are expressed in these cells before the formation of morphologically differentiated somatic embryos (Wild et al. 1988, Kiyosue et al. 1991, 1993a, 1993b, Lin et al. 1996, Tachikawa et al. 1998). For this reason, it has been postulated that embryogenic cells are already programmed for early- and late-stage embryogenesis at the molecular level, and it is difficult to efficiently isolate early embryonic genes using these cells (Kiyosue et al. 1991, 1993a, 1993b). However, in the stress-induction system, the induction of embryonic gene expression corresponds to the acquisition of embryogenic competence during stress (Kikuchi et al. 2006). The expression levels of early embryonic genes are thought to be enhanced under conditions of stress, and comparing expression profiles using the stress-induction system can help in isolating these genes. This study aimed to isolate novel embryo-specific genes, including those expressed in early-stage embryogenesis, using the stress-induction system of somatic embryos in carrots. There is little genomic information available for carrot and, 


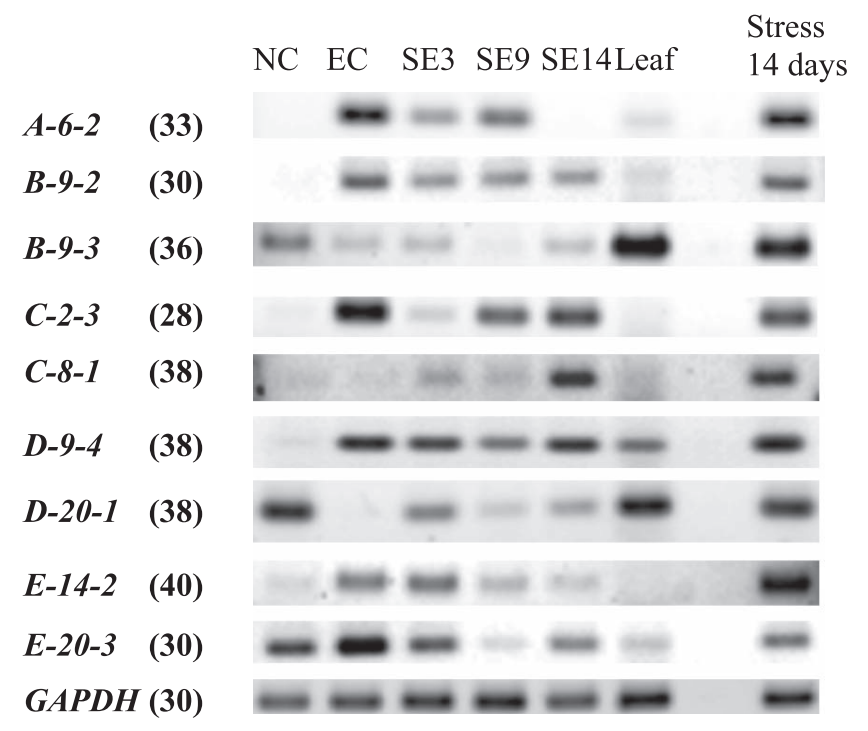

Fig. 5. Expression analysis in embryogenic cells and somatic embryos by RT-PCR. cDNAs were synthesized from total RNA isolated from embryogenic cells (EC), somatic embryos after 3, 9, or 14 days of induction (SE3, 9, 14, respectively), non-embryogenic cells (NC), or true leaves of 4-week-old plants (Leaf). Apical tip explants treated with $0.7 \mathrm{M}$ sucrose for 14 days (Stress 14 days) were used as a positive control. The genes were amplified using specific primer sets. Numbers of PCR amplification cycles are given in parentheses. GAPDH was used as an internal standard.

thus, FDD may be a useful method for comparing expression profiles on a large scale and for isolating candidate genes in this species. About 20,000 cDNA fragments were detected by FDD, 142 of which showed elevated expression levels during stress treatment (Fig. 1). However, only $19.0 \%$ of the clones (27/142) showed double the signal intensity upon stress treatment, as compared to controls (Fig. 2), and further screening by RT-PCR eliminated six of these clones. The remaining 21 were selected as stress-inducible genes. Therefore, among the 20,000 cDNAs detected by FDD, only about $0.11 \%$ were actually induced by stress treatment. In some studies using FDD, among observable cDNA bands, only about $0.03-0.12 \%$ of the isolated genes showed the expected expression profiles on further analysis (Hayama et al. 2002, Kidd et al. 2006, Higuchi et al. 2007).

To isolate genes corresponding to the acquisition of embryogenic competence, the expression profiles of 12 candidate clones were analyzed using 2,4-D to induce the formation of EC (Fig. 4). Among the 12 stress-induced clones isolated in this study, nine were induced by $2,4-\mathrm{D}$. However, of these nine, only five are expressed specifically in embryonic tissues, and the remaining four are expressed in both embryonic and non-embryonic tissues (Fig. 5). EC and NC are cultured in medium containing 2,4-D, and the five genes isolated as embryo-specific expressed genes were not expressed in NC. Furthermore, all five genes were also expressed in somatic embryos, which were induced from embryonic cells after transfer to 2,4-D free medium (Fig. 5).
A-6-2
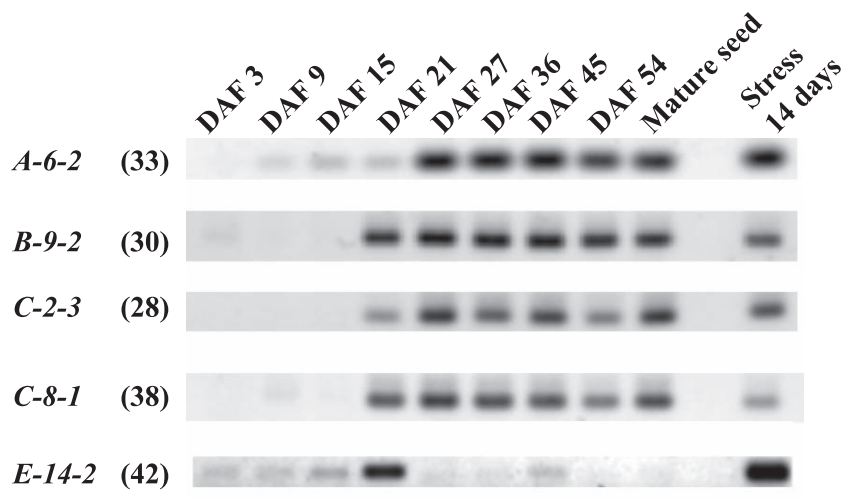

GAPDH(30)

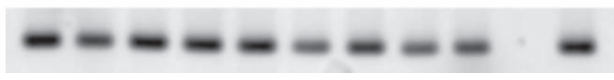

Fig. 6. Expression analysis during zygotic embryogenesis by RTPCR. cDNAs were synthesized from total RNA isolated from immature seeds on various days after flowering (DAF3, 15, 21, 27, 36, 45, and 54) and mature seeds. Apical tip explants treated with $0.7 \mathrm{M}$ sucrose for 14 days (Stress 14 days) were used as a positive control. The genes were amplified using specific primer sets. Numbers of PCR amplification cycles are given in parentheses. GAPDH was used as an internal standard.

This result suggests the possibility that these five genes were induced with induction of embryogenic competence, but not induced by mere 2,4-D treatment.

Auxin is an inducer of somatic embryogenesis, but it is also known to induce many kinds of physiological responses. It is quite likely that only some of the responses to auxin lead to embryogenesis. In carrot, auxin induces a callus with embryogenic competence. The response of explants to auxin is rapid, and auxin-treated explants express LEA in the early stage. Sucrose treatment leads the explants to an inactive state, although it can still induce embryogenesis. Our previous study revealed that various stress treatments induce embryogenesis (Kikuchi et al. 2006). The study also showed that the response of stress-treated explants is relatively slow. Since it is necessary to eliminate other physiological factors and LEA induction to screen embryo-specific genes, the embryogenesis-induction system by sucrose treatment was adopted.

Among the five clones that were actually expressed during embryogenesis, $A-6-2$ expression began at 9 DAF and continued to seed maturity, and $B-9-2, C-2-3$, and $C-8-1$ expression began at $21 \mathrm{DAF}$ and continued to seed maturity (Fig. 6). A-6-2 encodes heat shock protein 17.7 (Hsp17.7), which belongs to the low-molecular-weight heat shock protein family, and its ectopic expression increases thermotolerance (Malik et al. 1999, Ahn and Zimmerman 2006). B-9-2 encodes a protein with no homology to any previously reported protein, but is partially similar to a seed maturation protein isolated from Arabidopsis. C-2-3 encodes a seed maturation protein similar to glucose and ribitol dehydrogenase. $C-8-1$ encodes a putative aquaporin, TIP3.1, which is localized on the vacuolar membrane and transports water 
and some small solutes. In some species, TIP3 homologs have been reported to be expressed specifically in late-stage embryogenesis and mature seeds (Johnson et al. 1989, Hofte et al. 1992, Maeshima et al. 1994, Vander et al. 2006). Sequence information and expression profiles of the four genes isolated in this study suggest that they may be involved in seed maturation in the late stages of zygotic embryogenesis.

In contrast, during zygotic embryogenesis, the expression of E-14-2 was observed in the early embryonic stage at 21 DAF (heart or early torpedo-shaped stage; Shiota et al. 1998), but was not observed after 27 DAF (Fig. 6). E-14-2 encodes a putative ubiquitin-protein ligase containing a RING-finger domain. RING-finger proteins are a group of E3 ligases that mediate the transfer of ubiquitin to proteins and target substrates to the proteasome, an important part of the protein degradation system, via the ubiquitin/26S proteasome pathway (Glickman and Ciechanover 2002). Ubiquitinmediated proteasome pathways have been suggested to play an important role in the early stages of plant embryogenesis (Shen et al. 2002, Hellmann et al. 2003, Liu et al. 2004), and Arabidopsis mutants of RING-finger type E3 ligase show seed deficiency (Serrano et al. 2006). Based on these observations, E-14-2 was expected to be an embryospecific gene with an important role in early embryogenesis. The frequency of somatic embryogenesis and the expression levels of $C-A B I 3$ and $E C P s$ increase with increasing duration of stress treatment (Kikuchi et al. 2006). E-14-2 is specifically expressed in the heart and early torpedo-shaped stage of zygotic embryogenesis, but E-14-2 expression increases with increasing duration of the stress treatment that is used for the induction of somatic embryos, similar to the other isolated genes (Fig. 3). This result suggests that the genes that were specifically expressed at the early embryonic stage were induced during the stress treatment used for the induction of carrot somatic embryos. Furthermore, the result suggests that the expression levels of these genes increased with the duration of the stress treatment. Our study suggests that the stress-induction system of carrot somatic embryos is a useful tool for efficiently isolating genes specifically expressed in early embryogenesis.

We were able to isolate unique genes from carrot that are expressed during early embryogenesis by combining the appropriate experimental system with the use of FDD. Our strategy might be useful for other crops and species of interest for which genome information is lacking. In addition to plant species with advanced genomics projects, such as rice, wheat, maize, potato, tomato, and pine (http://www. tiger.org/plantProjects.shtml), other plant species exhibit many important physiological phenomena, such as absolute SD flowering in Japanese morning glory (Imamura 1967) and in-vitro double fertilization in Torenia fournieri (Higashiyama 2002). For such plant species, target genes might be able to be isolated using our systems.

\section{Acknowledgments}

This work was supported in part by a Grant-in-Aid from the Ministry of Education, Science, Culture, and Sports, Japan (number 16370017), and a Grant-in-Aid for Special Research on Priority Areas (number 19043007) to HK.

\section{Literature Cited}

Agre,P., L.S.King, M.Yasui, W.B.Guggino, O.P.Ottersen, Y.Fujiyoshi, A.Engel and S.Nielsen (2002) Aquaporin water channels: from atomic structure to clinical medicine. J. Physiol. 542: 3-16.

Ahn, Y.J. and J.L.Zimmerman (2006) Introduction of the carrot HSP17.7 into potato (Solanum tuberosum L.) enhances cellular membrane stability and tuberization in vitro. Plant Cell Environ. 29: 95-104.

Arabidopsis Genome Initiative (2000) Analysis of the genome sequence of the flowering plant Arabidopsis thaliana. Nature 408: 796-815.

Ausubel, F.M., R. Brent, R.E. Kingston, D.D. Moore, J.G. Seidman, J.A.Smith and K.Struhl (1987) Phenol/SDS methods for plant RNA preparation. In: Ausubel, F.M., R. Brent, R.E. Kingston, D.D.Moore, J.G.Seidman, J.A.Smith and K.Struhl (eds.) Current Protocols in Molecular Biology. Greene Publishing Associates and Wiley Interscience, New York, pp. 4.3.1-4.3.4.

Darwish,K., L.Q.Wang, C.H.Hwang, N.Apuya and J.L.Zimmerman (1991) Cloning and characterization of genes encoding low molecular weight heat shock proteins from carrot. Plant Mol. Biol. 16: 729-731.

Freemont,P.S. (1993) The RING finger. A novel protein sequence motif related to the zinc finger. Ann. NY Acad. Sci. 684: 174-192.

Giraudat, J., B.M. Hauge, C.Valon, J. Smalle, F. Parcy and H.M. Goodman (1992) Isolation of the Arabidopsis ABI3 gene by positional cloning. Plant Cell 4: 1251-1261.

Glickman,M.H. and A.Ciechanover (2002) The ubiquitin-proteasome proteolytic pathway: destruction for the sake of construction. Physiol. Rev. 82: 373-428.

Goldberg,R.B., G.dePaiva and R.Yadegari (1994) Plant embryogenesis: Zygote to seed. Science 266: 605-614.

Hatzopoulos,P., G.Franz, L.Choy and R.Z.Sung (1990) Interaction of nuclear factors with upstream sequences of a lipid body membrane protein gene from carrot. Plant Cell 2: 457-467.

Hayama, R., T.Izawa and K. Shimamoto (2002) Isolation of rice genes possibly involved in the photoperiodic control of flowering by a fluorescent differential display method. Plant Cell Physiol. 43: 494-504.

Hellmann,H., L.Hobbie, A.Chapman, S.Dharmasiri, N.Dharmasiri, C.delPozo, D. Reinhardt and M.Estelle (2003) Arabidopsis AXR6 encodes CUL1 implicating SCF E3 ligases in auxin regulation of embryogenesis. EMBO J. 22: 3314-3325.

Higashiyama,T. (2002) The synergid cell: attractor and acceptor of the pollen tube for double fertilization. J. Plant Res. 115: 149-160.

Higuchi, Y., K.Sage-Ono, H.Kamada and M.Ono (2007) Isolation and characterization of novel genes controlled by short-day treatment in Pharbitis nil. Plant Biotechnol. 24: 201-207.

Hofte,H., L.Hubbard, J.Reizer, D.Ludevid, E.M.Herman and M.J. Chrispeels (1992) Vegetative and seed-specific forms of tonoplast intrinsic protein in the vacuolar membrane of Arabidopsis thaliana. Plant Physiol. 99: 561-570.

Imamura, S. (1967) Photoperiodic induction and the floral stimulus. 
In: Imamura, S. (ed.) Physiology of Flowering in Pharbitis nil. Japanese Society of Plant Physiologists, Tokyo, pp. 15-28.

International Rice Genome Sequencing Project (2005) The map-based sequence of the rice genome. Nature 436: 793-800.

Joazeiro,C.A. and A.M.Weissman (2000) RING finger proteins: mediators of ubiquitin ligase activity. Cell 102: 549-552.

Johnson,K.D., E.M.Herman and M.J.Chrispeels (1989) An abundant, highly conserved tonoplast protein in seeds. Plant Physiol. 91: 1006-1013.

Kamada,H. and H.Harada (1979) Studies on organogenesis in carrot tissue culture. I. Effects of growth regulation on somatic embryogenesis and root formation. Z. Pflanzenphysiol. 91: 225-266.

Kamada,H., K.Kobayashi, T.Kiyosue and H.Harada (1989) Stressinduced somatic embryogenesis in carrot and its application to synthetic seed production. In Vitro Cell Dev. Biol. 25: 1163-1166.

Kamada,H., K.Ishikawa, H.Saga and H.Harada (1993) Induction of somatic embryogenesis in carrot by osmotic stress. Plant Tissue Cult. Lett. 10: 38-44.

Kamada,H., Y.Tachikawa, T.Saitou and H.Harada (1994) Heat stress induction of carrot somatic embryogenesis. Plant Tissue Cult. Lett. 11: 229-232.

Kidd, S.K., A.A. Melillo, R.H.Lu, D.G.Reed, N.Kuno, K.Uchida, M.Furuya and J.G.Jelesko (2006) The $A$ and $B$ loci in tobacco regulate a network of stress response genes, few of which are associated with nicotine biosynthesis. Plant Mol. Biol. 60: 699-716.

Kikuchi,A., N.Sanuki, K.Higashi, T.Koshiba and H.Kamada (2006) Abscisic acid and stress treatment are essential for the acquisition of embryogenic competence by carrot somatic cells. Planta 223: $637-645$.

Kiyosue,T., H.Kamada and H.Harada (1989) Induction of somatic embryogenesis by salt stress in carrot. Plant Tissue Cult. Lett. 6: 162164.

Kiyosue,T., K.Takano, H.Kamada and H.Harada (1990) Induction of somatic embryogenesis in carrot by heavy metal ions. Can. J. Bot. 68: 2021-2033.

Kiyosue,T., S.Satoh, H.Kamada and H.Harada (1991) Purification and immunohistochemical detection of an embryogenic cell protein in carrot. Plant Physiol. 95: 1077-1083.

Kiyosue, T., K. Yamaguchi-Shinozaki, K. Shinozaki, K. Higashi, S.Satoh, H.Kamada and H.Harada (1992) Isolation and characterization of cDNA that encodes ECP31, an embryogenic-cell protein from carrot. Plant Mol. Biol. 19: 230-249.

Kiyosue, T., S.Satoh, H.Kamada and H.Harada (1993a) Somatic embryogenesis in higher plants. J. Plant Res. Special Issue 3: 75-82.

Kiyosue,T., K.Yamaguchi-Shinozaki, K. Shinozaki, H.Kamada and H.Harada (1993b) cDNA of ECP40, an embryogenic-cell protein in carrot, and its expression during somatic and zygotic embryogenesis. Plant Mol. Biol. 21: 1053-1068.

Lin, X., G.J.Hwang and J.L.Zimmerman (1996) Isolation and characterization of a diverse set of genes from carrot somatic embryos. Plant Physiol. 112: 1365-1374.

Liu,F., W.Ni, M.E.Griffith, Z.Huang, C.Chang, W.Peng, H.Ma and D.Xie (2004) The $A S K 1$ and $A S K 2$ genes are essential for Arabidopsis early development. Plant Cell 16: 5-20.

Lotan, T., M. Ohto, K.M. Yee, M.A.West, R. Lo, R.W. Kwong, K.Yamagishi, R.L.Fischer, R.B.Goldberg and J.J.Harada (1998) Arabidopsis LEAFY COTYLEDON1 is sufficient to induce embryo development in vegetative cells. Cell 93: 1195-1205.

Maeshima, M., I. Hara-Nishimura, Y.Takeuchi and M.Nishimura (1994) Accumulation of vacuolar $\mathrm{H}^{+}$-pyrophosphatase and $\mathrm{H}^{+}$ ATPase during reformation of the central vacuole in germinating pumpkin seeds. Plant Physiol. 106: 61-69.

Malik, M.K., J.P.Slovin, C.H.Hwang and J.L.Zimmerman (1999) Modified expression of a carrot small heat shock protein gene, Hsp17.7, results in increased or decreased thermotolerance. Plant J. 20: 89-99.

McCarty,D.R. (1995) Genetic control and integration of maturation and germination pathways in seed development. Annu. Rev. Plant Physiol. Plant Mol. Biol. 46: 71-93.

Müller,M., L.Kruse, A.M.Tabrett and D.J.Barbara (1997) Detection of single base changes in PCR-amplified DNA fragments using agarose gel electrophoresis containing bisbenzimide-PEG. Nucl. Acids Res. 25: 5125-5126.

Murashige,T. and F.Skoog (1962) A revised medium for rapid growth and bioassays with tobacco tissue cultures. Physiol. Plant. 15: 473497.

Nambara, E., R. Hayama, Y.Tsuchiya, M. Nishimura, H. Kawaide, Y.Kamiya and S.Naito (2000) The role of $A B I 3$ and FUS3 loci in Arabidopsis thaliana on phase transition from late embryo development to germination. Dev. Biol. 220: 412-423.

Parcy,F., C.Valon, A.Kohara, S.Misera and J.Giraudat (1997) The ABSCISIC ACID-INSENSITIVE3, FUSCA3, and LEAFY COTYLEDON1 loci act in concert to control multiple aspects of Arabidopsis seed development. Plant Cell 9: 1265-1277.

Reinert,J. (1959) Uber die Kontrolle der morphogenese und die induction von adventivembryonen an Gewebekulturen aus Carotten. Planta 53: 318-333.

Santos Mendoza, M., B. Dubreucq, M. Miquel, M.Caboche and L.Lepiniec (2005) LEAFY COTYLEDON 2 activation is sufficient to trigger the accumulation of oil and seed specific mRNAs in Arabidopsis leaves. FEBS Lett. 579: 4666-4670.

Satoh, S., H.Kamada, H.Harada and T.Fujii (1986) Auxin-controlled glycoprotein release into the medium of embryogenic carrot cells. Plant Physiol. 81: 931-933.

Serrano,M., S.Parra, L.D.Alcaraz and P.Guzman (2006) The ATL gene family from Arabidopsis thaliana and Oryza sativa comprises a large number of putative ubiquitin ligases of the RING-H2 type. J. Mol. Evol. 62: 434-445.

Shen, W.H., Y.Parmentier, H.Hellmann, E. Lechner, A. Dong, J. Masson, F.Granier, L.Lepiniec, M.Estelle and P.Genschik (2002) Null mutation of AtCUL1 causes arrest in early embryogenesis in Arabidopsis. Mol. Biol. Cell 13: 1916-1928.

Shiota,H., R.Satoh, K.Watabe, H.Harada and H.Kamada (1998) C$A B I 3$, the carrot homologue of the Arabidopsis ABI3, is expressed during both zygotic and somatic embryogenesis and functions in the regulation of embryo-specific ABA-inducible genes. Plant Cell Physiol. 39: 1184-1193.

Steward,F.C., M.O.Marpes and K.Mears (1958) Growth and organized development of cultured cells. I. Growth and division of freely suspended cells. Am. J. Bot. 45: 693-703.

Stone, S.L., L.W. Kwong, K.M. Yee, J. Pelletier, L. Lepiniec, R.L.Fischer, R.B. Goldberg and J.J.Harada (2001) LEAFY COTYLEDON2 encodes a $\mathrm{B} 3$ domain transcription factor that induces embryo development. Proc. Natl. Acad. Sci. USA 98: 11806-11811.

Sung,Z.R., A.Fienberg, R.Chorneau, C.Borkird, I.Furner and J.Smith (1984) Developmental biology of embryogenesis from carrot culture. Plant Mol. Biol. Rep. 2: 3-14.

Tachikawa,Y., T.Saitou, H.Kamada and H.Harada (1998) Changes in protein pattern during stress-induction of carrot (Daucus carota $\mathrm{L}$ ) somatic embryogenesis. Plant Biotechnol. 15: 17-22.

Thomas,D., P.Bron, G.Ranchy, L.Duchesne, A.Cavalier, J.P.Rolland, 
C. Raguénès-Nicol， J.F. Hubert， W. Haase and C. Delamarche (2002) Aquaglyceroporins, one channel for two molecules. Biochim. Biophys. Acta 1555: 181-186.

Vander Willigen,C., O.Postaire, C.Tournaire-Roux, Y.Boursiac and C.Maurel (2006) Expression and inhibition of aquaporins in germinating Arabidopsis seeds. Plant Cell Physiol. 47: 1241-1250.

Vicient,C.M., N.Bies-Etheve and M.Delseny (2000) Changes in gene expression in the leafy cotyledon1 (lec1) and fusca3 (fus3) mutants of Arabidopsis thaliana L. J. Exp. Bot. 51: 995-1003.
Wilde,H.D., W.S.Nelson, H.Booij, S.C.de Vries and T.L.Thomas (1988) Gene-expression programs in embryogenic and nonembryogenic carrot cultures. Planta 176: 205-211.

Yazawa,K., K.Takahata and H.Kamada (2004) Isolation of the gene encoding carrot leafy cotyledon1 and expression analysis during somatic and zygotic embryogenesis. Plant Physiol. Biochem. 42: 215-223.

Zimmerman,J.L. (1993) Somatic embryogenesis: A model for early development in higher plants. Plant Cell 5: 1411-1423. 